\title{
12 \\ Plaited textile expression in Lapita ceramic ornamentation
}

\author{
Wallace Ambrose
}

In some areas of Polynesia, the fibre and textile arts are ranked equally with, or even more importantly than, carving traditions (Kaeppler 2008:11).

\begin{abstract}
Oceanic art styles are often seen as having their origin in the detailed and elaborately executed dentate stamp ornamentation of Lapita pottery, as fragments, unheralded in the Bismarck Archipelago until around 3300 years ago from where it spread to later settlements in Vanuatu, New Caledonia, Fiji, Tonga and Samoa. The distinctive Lapita vessels include platters, plates, bowls and cylinder stands bearing designs notable for their formal arrangement of repeating units within panels arranged in horizontal bands. Later archaeological research produced whole vessels with entire design fields, giving a clearer expression of the wealth and range of Lapita originality in the ornamentation of these ceramics. Ethnographically recorded Oceanic tattoo, tapa and wood-carving designs are often thought to have received their inspiration from ancient Lapita pottery decoration. This chapter argues conversely that the transfer of designs is to Lapita ceramics, from plaiting and basketry as the dominant, more fundamental, enduring and geographically extensive influence, with implications for later ceramic production and changing social organisation in Polynesia.
\end{abstract}

\section{Introduction}

Lapita pottery is a primary signal for the arrival, foundation, dispersal and transformation of societies from the Bismarck Archipelago to the West Polynesian settlements in Tonga, Samoa and Fiji. Much effort over the last 50 or so years was spent on describing and analysing the pottery's changing form and main decorative features that range from tightly controlled dentate-stamped ornamentation to more freely incised designs, as well as plain undecorated wares, all based on collections of Lapita sherds. The earliest systematic and informative analysis of Lapita design was inspired by Mead's survey of Polynesian adze binding and haft decoration (Mead 1971, 1974). His treatment of the adze's decorative features in a formal way was based on a linguistic model, with a design element vocabulary, cognate forms and constructed proto-vocabularies (Mead 1971, 1974:726 and Table 1). This innovative system was applied to Lapita collections from Fiji and the results compared with other Lapita sherd collections from Tonga, New Caledonia, Vanuatu and Watom in East New Britain (Mead et al. 1973). Despite the very few pottery 
collections available to Mead, his conclusion about the relative site succession implied by the changes of decorative features has been confirmed for the settlement history of Tonga-Fiji (Burley and LeBlanc 2015:177).

Green (1979a:42) applied the Mead 'linguistic' model systematically to record the decoration on Lapita vessels but emphasised the need for a broader view to include complete vessel forms independently from the attractive designs. In effect, Green treated the surface design as a study separate from a vessel's form. This was an important but unnecessary distinction because it is clear that some vessels were specially made to display the design, and to a great extent were unique products. Mead also saw 'that a decorative system can exist independently of the artefacts to which it is applied' and that ' $\mathrm{t}$ ] he design elements used on the Sigatoka [Fiji] pottery were not necessarily applied only to ceramics but could have been applied to textiles, woodcarving and tattooing as well' (1973: Part 2:20). This 'separation' is too artificial in cases where the decorated area on complete Lapita vessels is rendered on finer clay fabric than the rest of the pottery body, or where extra thickness was imparted to the decorated carinated area to allow for extra strength (Sand 2015:126), presumably to maintain the larger-sized pot form while the impressed surface decoration was made, or the fragile ware was being fired. These are integrated, specially made pottery forms designed to display the important designs. Although Green's study of the whole ceramic as part of the Lapita Cultural Complex was a balanced approach, 'it must be said that our working models still largely rest on the study of the intricately decorated Lapita pots' (Sand 2007:265).

Mead's formal method for identifying the basic geometric repeating design units, constrained within one or more horizontal bands between zone markers (Mead 1973:20), prompted the idea of design continuity realised ethnographically in motifs recorded in tapa and tattoo, therefore accepting that there were deep structures having a continuous development from the formal elements of a Lapita art style to a later Polynesian decorative tradition (Green 1979b, 1990:38; Kirch 1997:142). Mead appeared more cautious than other researchers in fully applying his analytical model to correspondences in design between simple units found between widely dispersed locations from Polynesia to Asia. He made the qualification 'that many of these units have a near universal distribution; that is to say, they are so simple that the possibility of independent invention can never be entirely discounted' (Mead 1971:495). The design units he referred to included triangular, chevron and diamond forms, the 'eye' motif, the single spiral and the basket weave. Taylor (1960:52) identified likeness in simple geometric designs between Polynesian plaited mats, bark cloth, carved wooden house posts, bowls and war clubs. Sand (2007:273) illustrated Lapita motifs that would comfortably align with figures presented by Taylor. Clearly, comparisons between the corpus of later Polynesian designs in different media and Early Lapita pottery may include a set of shared basic units that are difficult to source uniquely from Lapita decoration, especially since many of the historically recorded Polynesian items have designs that bear little resemblance to pre-contact examples, for example in Tahitian tapa (Kooijman 1988:20; Thomas 1999:12).

Despite Mead's caution, there was a statistical need to expand the number of design units and motifs to allow for comparisons between additional sherd collections separated by age and location (Green 1990:36). The proliferation of elements from the subsequent splitting of motifs was greatly extended-for example, by Anson (1986:160, 1990:57) who subdivided triangle design units by counting the number of their infill lines to identify connections between local sites in the Bismarck Archipelago. Spriggs (1990:83) and Best (2002:40) noted the inadequacy of an approach that dwelt on smaller fractions of the original designs but, inevitably, most early research projects were limited to motif statistics from vessel fragments. Sharp (1988:62) had already concluded from her review that the motif design data of other researchers was defined 
by intuitive and inconsistent criteria. Green's review (1990) of studies during the previous 20 years similarly reported a lack of agreement in unifying the systematics of basic Lapita design motifs. This view was affirmed by Chiu's attempt to cross-correlate the basic elements of Lapita design from other databases that 'remains a difficult, if not impossible task' (2003:171), while Best's review was simply critical of efforts to connect Lapita design with historic Polynesian art (2002:55). It appears that Lapita design analysis had pursued its own atomising course. Spriggs (1990), after identifying the iconic Lapita 'face', finally lamented his 'frustration at the way we have been forced to examine the Lapita design system on the basis of often very fragmentary sherds' and that 'once the "Mead system" and its variants were well-established within Lapita studies it seemed impossible to get out of this almost microscopic focus to see the faces among the eyes and noses' (Spriggs 2002:51). This view is now countered by the computer-based social network analytical possibilities of the Lapita Pottery Online Database established by Chiu (2015), who is able to extract more information from advances in standardised motif definitions. For example, the transformation of the 'face' motif (Chiu 2005, 2007) implying an increased social distance between founding Lapita populations. Chiu's latest motif analytical system builds on the pioneering work of Mead by defining associated changes of the Lapita design system as expressions of settlement network connections over time. On the other hand, Burley and LeBlanc (2015:181) find that computer analysis of Lapita motifs can obscure differences that visual observation successfully makes clear to them.

\section{Transformations}

The design reduction of classic Early Lapita over time to a later appearance of simpler, less elaborate decoration indicates a decline or change in their inherent message from some clearly important social and ritual performance. It would be easy to say that any integrated ceremony likewise declined, but there is no evidence for what the ceremony might have been. This has led to a suggestion, for instance, that they began as ritual vessels for serving high-status food such as turtles (Marshall 2008:72), echoed in a claim by Terrell and Schechter (2009) that within the dentate-stamped designs there are recognisable figures based on turtles. This is contrary to the views of Spriggs (1993), Chiu (2005) and others that the recognisable image is a face representing an important person such as a founding ancestor of a 'house based' society (Green 2002:25). Or it may simply represent a mask, according to Gorecki (1996; see also Spriggs this volume). Rather than trying to translate the meaning of the complex designs, Summerhayes has cited the relative connectivity between communities within the West New Britain and Emirau sites that shared Lapita motifs (Summerhayes 2001; Summerhayes et al. 2010). Dickinson and Shutler (2000:238) note multiple instances of ceramic transfer over distances of 100 to $500 \mathrm{~km}$ based on temper petrography in the Bismarck Archipelago. The comparisons that Summerhayes makes, using a broad set of factors, show that raw material sources, plain and decorated pot differences, and shared motifs were all part of the production strategy. That the products all converge as like forms from the use of different local and exotic fillers and clays shows that a mutually shared information exchange system was in place covering a network of sites. It implies that the potters themselves may have moved to maintain the intricate Lapita design system but, significantly, producing unique individual vessels. Later Lapita pottery has raw materials collected locally with more conservative and standardised production (Summerhayes and Allen 2007:107). This again raises the question of who made the pots. It could be argued that this is likely to be a case of exogamy where female potters carried their skills to related communities with their local raw material sources, in which case they could be the design curators of personal 'house' or 'cottagebased' products. Kirch (2000:107) uses the area of his early Talepakemalai site on Mussau Island to estimate that Lapita settlement sites could vary between hamlets of fewer than 10 dwellings, 
to sites that could constitute a modest village between 15 to 30 dwellings. Ambrose (1997:529) cites several observations on the ceramic technology of the early highly ornamented Lapita pots that were porous and fragile from using a high sand-filler to clay ratio for different parts of the same pot, and by being fired at a low temperature; showing they were not intended for long-term serviceable use but designed for limited display.

Clark (2007) compares the greater size and design density of Early Lapita vessels from New Caledonia site WKO013A that differ significantly from later wares from the Fijian Sigatoka site. He affirms the view of Chiu (2005) and others that the early dentate-stamped pots were produced for local ceremonial use and demonstrates that Lapita was not simply a blank vessel independent from the specialised nature of its surface design. Sand's carefully illustrated and sweeping study of Lapita design over time and across its geographic range also notes that 'there appears to be a greater diversity of motif composition on individual pots in the Far Western-Early Lapita when compared with the more standardised sets of motifs seen later' (Sand 2015:140). The resulting progressive separation of the early pot-decoration unity over time led in one case to the standardised trade ware of the recent Motu women potters of south coast Papua New Guinea who produced thousands of similar pots, with minimum or no decoration, that were carried on large multiple hull canoes over three to four sailing days away in the Papuan Gulf for exchange with trading partners who supplied sago in return (Groves 1960). This in a region where there was continuity in pottery production from Late Lapita (David et al. 2011). In contrast, the loss of Lapita pottery's social cogency accelerated after settlement in Tonga-Samoa around $2850 \mathrm{cal}$. BP, when elements of the early Western Lapita-style pottery changed rapidly towards increasing design and vessel standardisation, leading to its complete abandonment two centuries later (Burley and LeBlanc 2015:177). The decline of a formerly valued and important artefact that required sophisticated and labour-intensive production indicates that its particular ceremonial function was rejected with changes in social organisation that could be translated through a different medium. In any case, the Lapita distribution network has no parallel in either the modern Motu trading system or centralised hierarchical systems of Polynesia.

\section{Wider influences}

As argued by Bellwood (1997:235), the discovery of red-slip dentate-stamped pottery from around 3400 years ago in the Philippines Cagayan Valley (Hung et al. 2011; Tsang 2007:83) provided an important contribution to the debate about the origins of the Lapita Cultural Complex and the derivation of the pottery's intricate design system. Carson et al. (2013:22) note five similarities in ceramic attributes in his 'pottery trail' between the Philippines, Marianas and Lapita collections. These include red-slipped finish; carinated vessel forms; placement of the decoration in most prominent display areas; a decorative 'point impression' technique that includes single and multipoint tools; and, lastly, decorative motifs including horizontal lines as boundary markers for more complex designs. This regional picture, based on evidence of long-range connections in the archaeological record, questions the adequacy of the conventional broad-scale ethnographic divisions between Micronesia, Melanesia and Polynesia. The wide range of cultural influences that began in simpler form over 3500 years ago between regions distant from each other are more elaborately expressed in Vanuatu Lapita pottery at the Vao (Malakula) site with the selective lime overpainting of broad decorated dentate bands, horizontally separated by narrow undecorated red ochre bands (Bedford 2006). Pre-Lapita social networks in the Bismarck Archipelago existed that could facilitate regional scale cultural changes (Torrence and Swadling 2008). A major review of the Lapita Cultural Complex (Specht et al. 2014) has suggested far more complexity in the formation of the social groups in New Guinea's Bismarck Archipelago than a simple incursion that stamped its progress from Island Southeast Asia to Polynesia. 
Green's (1991:298) three-way model for cultural 'intrusion, integration and innovation' gives imprecise relative weight to these categories, as more information is found through archaeology and contributing studies from biological and materials analysis; a concern also expressed by Davidson (2012) in her analysis of settlement history of Samoa and several Polynesian Outliers. The three-factor model could, of course, be applied to any level of social change in any social group, simply because these factors are a constant feature of societies of any size, from family units to large settlements. A connection between the pottery technology of the Philippines, Marianas and Lapita is clear (although see Chapter 2, this volume, for another perspective), but the immediate source of the complex Lapita design motifs and their execution on vessels specially constructed to display the designs is still to be found. This leads to the question of why the overall design complexity may have arisen. Any argument using ethnographic similarities that could yield comparisons from over 3000 years ago is untestable, but until direct precursor decorated pottery is found outside the Bismarck Archipelago to suggest 'intrusion, integration or innovation', it appears that the elaborate dentate-stamped Lapita ware can be seen as a product of local influence from the time of the pottery's introduction to the New Guinea region. The widespread use throughout New Guinea of flamboyant, highly decorative ceremonial artefacts such as masks, shields and other carved items no doubt has a deep prehistory. In comparison, bare minimum dress covering is the norm in the coastal tropics, complemented with personal decorative attire of cuffs, armbands, belts and girdles made from bark and fibre with attached decorative objects for special occasions, such as that described as The Rich Variety of Textile Art in Manus (Ohnemus 2002). Bark belts with plaited fibre overlays are used in the New Guinea Highlands (Pendergrast 2005:65), with simple incised lime-filled versions in the Papuan Gulf (Lewis 1973:87). An apparent florescence of Lapita design in the New Guinea region could reflect elements of cultural encounters with local populations and their decorative artistry.

\section{The missing textiles}

The late Roger Green's major lifetime contribution to archaeology in Oceania included his very influential view concerning the persistence of Lapita design that was apparent in later materials as presented in his paper 'Early Lapita art from Polynesia and Island Melanesia: Continuities in ceramic, barkcloth, and tattoo decorations' (Green 1979b). Surprisingly, Watom, the site that Green analysed in depth, had a description of the original 1909 Lapita sherds by Casey (1936:97), who noted that Indonesian baskets and rattan mats from Borneo and Sumatra shared similar patterns. It is difficult to understand why textiles other than tapa were not included in Green's list, but it was probably based on Mead's $(1971,1973,1974)$ approach that prompted the idea of design continuity through to the motifs recorded in tapa and tattoo. From there it proceeded to a bias in confirming that Lapita was the recipient of tattoo design, or vice versa (Green 1985:220). The inclusion of Polynesian tattooing patterns as a continuation of Lapita design was probably influenced by the fact that both employ multiple pointed tools in producing their designs. But this supposed connection between the tool kits of multiple pointed tattoo implements as used in Polynesian tattooing and Lapita dentate stamping is not credible based on the ethnographic and archaeological record (Ambrose 2012). Taylor (1960) illustrated element transfers from basketry and plaiting to Polynesian tapa among other instances of fabric design transfer to different materials. As a basic material, barkcloth must have continuity since arriving with the first settlers into the Pacific from Island Southeast Asia (Kooijman 1988:16). Apart from being a useful and ceremonially valuable fabric it allows for great design diversity, from freehand painting to applied stampings. 
Tapa, plaiting and basketry are basic technologies with inherent design characteristics that nevertheless allow flexibility and innovation in the hands of skilled artists. Marshall has suggested (1985:224) that the demise of Lapita pottery in Polynesia was eventually replaced by women potters moving their skills to a 'new medium-fine mats and tapa cloth'. This proposition may have some merit for plaited textiles, fine mats and tapa but artefacts including wickerwork, plaiting and other elaborate fibre artefacts may equally be male productions. Kirch (1997:152) sees the evidence of different finishes and quality between decorated and undecorated Lapita ceramics is a result respectively of male and female production. Buck (1926:141) observed that the uniquely twined elaborate tāniko borders on Māori cloaks were originally plaited by men in New Zealand. Ethnographically, tattooing is a male technology in Polynesia but mainly a female occupation in the Western Pacific (Ambrose 2012) from where Lapita settlements began.

\section{Fibre-based design}

Fibre products are fundamentally important items throughout the non-metal-using societies of the Pacific. It is not difficult to recognise similarities between the overall composition of Lapita decoration and its derivation from patterned textiles. One hundred and twenty years ago, Alfred Haddon (1895:75) and later Childe (1956:13) used the term 'skeuomorph', applied to artefacts that are decorated by the natural appearance of a different material. This term could be applied to the design on Lapita pottery as a skeuomorph of plaited fibre items (Figure 12.1).

Patterns on fibre-bound artefacts such as adze hafts or house beams are often cited as being 'like' Lapita but without the implication that the pottery design derives from fibre patterns. For example, Bedford et al. (2010:36) liken the layout of the labyrinth motif to weaving patterns, while Sand (2010:197) draws attention to the similarity between the decorative sennit binding on Tongan house beams and Lapita surface designs. In contrast, Pendergrast (2000:45) cites a Tikopian example where the patterns of coconut fibre bindings on house posts are specifically used as a tattoo motif. As plaiting and basketry designs are relatively constrained by their technology in comparison with pottery decoration, if there is 'likeness' between motifs in Lapita ceramic decoration and textile patterns, then textile is more likely to be the source of the derived pottery ornamentation.

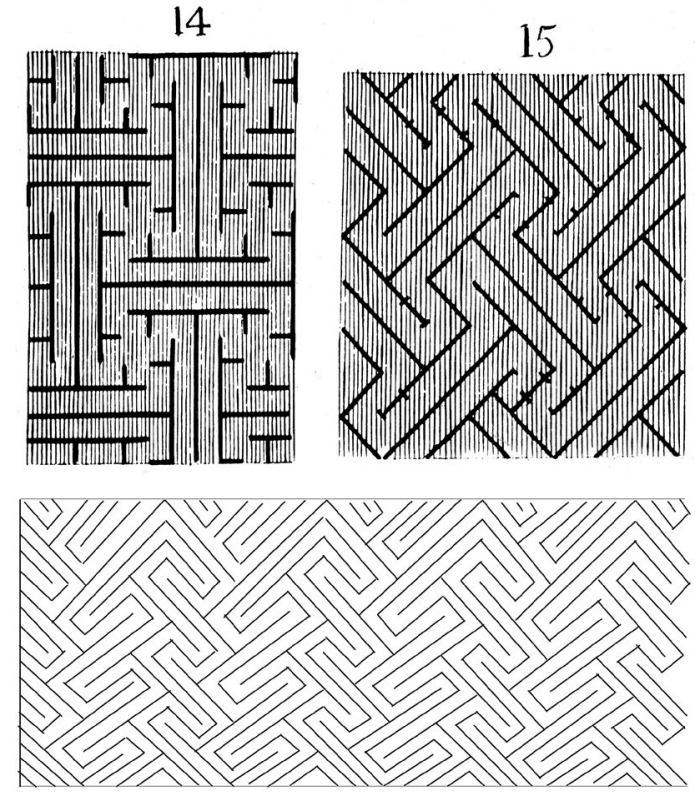

Figure 12.1. Haddon (1895:97) gives examples of pottery 'skeuomorphs' of weaving as illustrated (p. 346) in Plate 4; No. 14 is from a Japanese fret, No. 15 is an Anglo-Saxon fret.

Haddon also illustrates other skeuomorph examples of artefact binding (p. 340) in Plate 1, wattle work (p. 342) in Plate 2 and basketry in Plate 3. Below for comparison is an example of the 'maze' repeated from a Teouma site Lapita pot.

Source: Taken from Haddon 1895; lower drawing by the author. 
There is a distributional difference in Oceania between hand plaiting of textiles and the later introduction to the Western Pacific of loom weaving (Intoh 1999:417). The main technique for producing fibre-based artefacts is finger plaiting, which produces a distinctive qualitative difference from loom-based woven materials. Te Rangi Hiroa's analysis (Buck 1930) of Samoan material culture distinguishes plaiting from weaving by reference to the so-called 'commencement edge' where two or more interlinking sets of fibre material cross diagonally to produce the plaited fabric (Emery 1980:60). Both the commencement edge and a complementary finishing edge can produce continuous edge zones, some with tassels that border the main fabric. Plaiting would basically favour diagonal grid-based geometric designs. Whereas twining, where the horizontal weft is interlaced with the vertical warp (Pendergrast 2005:18), tends to produce a basic rectangular grid. Both these fibre techniques are capable of producing intricate designs with attachments, interleaving motifs and open elements. Plaiting and its variants are the basis for the commonly seen utilitarian materials throughout Oceania such as floor mats, baskets, wall screens, canoe sails etc. Basketry has been used to form sculptures and other three-dimensional forms. Plaiting is also used to combine fibres into cordage that is essential for various purposes such as binding and lashing, and seen as ornamental features of building construction or, as Mead (1974) has shown, for adze fastenings. For Oceanic coastal societies dependent on canoe-based resources, fibre is an essential construction material.

The role of plaited fibre encompasses a wide range of functions from those at one extreme in the open string 'cats-cradles' from Kiribati where Maude (1958:2) describes around 180 named configurations. The plaited matting designs from Palau recorded by Kubary in 1895 (illustrated in Krämer 1926:143) are diverse enough to have separate names and functions.

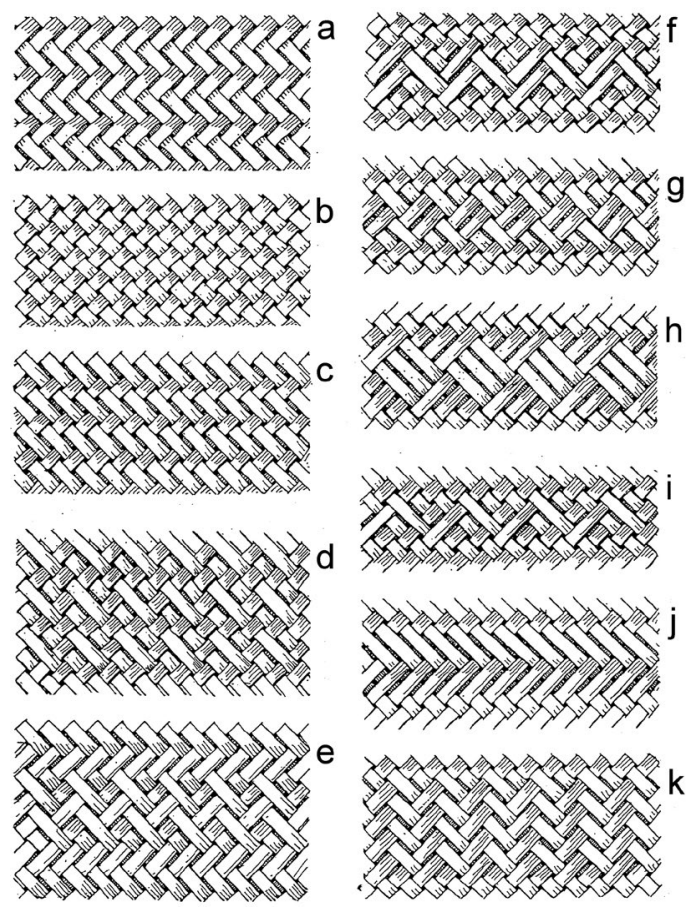

Figure 12.2. Eleven simple plaited designs have ascribed purposes according to Krämer (1926:143), based on the records of Kubary (1895).

The ascriptions seem lacking in detail, but the named patterns do show that variety can be achieved in basic plaited work. (A) Arm binding patterns in 2:2 twill basketry plait, from this ordinary pattern sleeping mats are mainly manufactured; (B) simple plain plait 1:1 used for sleeping mats and wrapping corpses; (C) braided oblique bands 1:2 'for the unmarried'; (D) oblique stripe 1:3 'support of the spirit/soul'; (E) main band and edge 1:2:3 'hermit crab track'; (F) 'crab claw zigzag'; $(\mathrm{G})$ unknown meaning; $(\mathrm{H})$ may refer to the duk fish with its rather square form; (I) zigzag of crosses as in the blasak tattoo motif; (J) the bush Mussaenda frondosa; (K) unknown meaning. Source: From Krämer 1926.

A similar example of the significant ceremonial role of basic fibre work is from Indonesia. Ellen (2009) discusses the concept of cognitive domain to describe the important place that basketry has in the Maluku Nuaulu community who are an animist group without pottery but with 17 kinds of basketry, each with a separate name and designed for different purposes. A particularly important lidded version, 'nuite', (Ellen 2009:254) is used for female and male initiation ceremonies that include carrying special food mixtures for the initiates. The rituals cannot be performed without the designated containers and failure to observe strictly the correct plaited patterns 
will adversely affect the success of the ritual. The motifs 'have a strong link to individual clans or "houses", and overall patterns to individual female weavers' (Ellen 2009:268). Although there are strictly observed uses for these baskets with their named plaited motifs, not one is identical to another.

In contrast to simpler basketry, an elaborate, highly valued ceremonial garment from the Tuamotus is a chief's sacred crimson girdle, described as 'beautifully plaited pandanus matting, elaborately fringed and dyed a dull crimson' (Emory 1975:72). D'Alleva (1998:137) outlines the role of special textiles in the Marshall Islands that were produced exclusively for high-ranking individuals and lineages, especially the intricately plaited clothing mats. Ohnemus (2002) illustrates personal adornments from the Admiralty Islands seen in the plaited and interleaved braided bands applied to parts of the body from head, arms, waist, leg or ankle, and in the dancing aprons reserved for ceremonial occasions. Bolton's study (2003:106) of women's exclusive production of Vanuatu plaited textiles underlines the need to understand the social role of individual items that in local usage do not simply come under a portmanteaux translatable term such as the English 'mat', as translated from Speiser (1996:236). Speiser illustrates (Plates 68 to 75) a record of the diverse and elaborate plaiting patterns achieved in his 'mats' from Vanuatu. These are similarly presented from Vanuatu in other papers by Walter, Bolton and Huffman (all in Bonnemaison et al. 1996), where special textiles are intrinsic to the ceremony and display of social status including food presentations. A highly ornamented hafted ceremonial adze from Mangaia (Thomas 2012:291) has a fine sennit binding design simulating fibre work in the elaborately carved wooden handle. Gill observed that the sennit, the haft and the adze itself were all made by 'priests' who 'chanted in a soft low tone to the gods to aid their work' (Gill 1885:224). In this regard, the classic Polynesian fabrics produced with such finesse in Samoa and Tonga must be another high point in unadorned plaiting technology used for ceremonial occasions. Pendergrast (2005:20) describes Māori plaiting that includes braiding to produce strips, belts and elaborately plaited and twined fabrics as productions of 'the sacred thread' (Pendergrast 1987).

\section{Fibre-based artefacts as evidence for Lapita pottery design}

The characteristic appearance of fibre-based design compositions can be seen in the shared productions of the Lapita ceramic practitioners. The application of intricate designs to a range of vessel forms implies a source of inspiration represented by a coherent 'school' of ceramic artistry that had some binding rules. Some of the characteristic features include:

i. Repeating symmetry as a primary characteristic of plaited textiles in the repetition of basic patterns inherent in the plaiting, twining or interlacing process. Twining is a universal characteristic of fibre-based containers such as those of Aboriginal Australians (Bolton 2011) or recent Māori artistry (Evans and Ngarimu 2005; Pendergrast 2005).

ii. Supplementary friezes are additional fabric edge techniques seen reflected in Lapita design as decorative margins (Siorat 1990). Siorat's study recognises the importance of edge features in Lapita design whereas Mead wrote (1973:21) that 'strictly speaking, the boundary markers which confine patterns into restricted space are not design elements'. These zone markers are a visual effect of the repetitively stamped edge zone bands that are commonly seen in Lapita designs. This is a feature of plaited fabric designs where borders constrain the design and may include decorative fringed edges. The repeating triangle marking the lower edge of friezes is commonly seen in Lapita pots. The triangle is sometimes given curved outlines as if to illustrate short tassels, as illustrated by Sand (2007:272) and Bedford et al. (2010:153). 
iii. Inversion patterns are present in simple plaiting/basketry designs, where it is sometimes difficult to resolve whether the intended pattern was positive, negative or both. This effect is seen in Sand's (2015) Lapita design survey illustrations and in the Kubary plaiting examples illustrated by Krämer (1926:143) in Figure 12.2.

iv. Joins and fastenings are used in plaited fabrics formed into wearable items, and these may be indicated on some Lapita decorated vessels with vertical sets of applied nubbins, as for instance from New Caledonia’s eponymous Lapita Site 13 (Sand 1999:45, Figure 3) or impressed circles on a dish decoration (Bedford et al. 2007:235). Hook-like nubbins found on some Vanuatu Teouma site pottery could be used for hanging decorative attachments.

v. Garments in Oceania that include finely plaited belts, girdles, aprons, capes and mantels appear to have similarly designed patterns in some of the larger Lapita vessels, where the impression of a garment is created by large ratio of a broad carination surface compared with the spherical shape of the pot base. The enhanced width of carination is used as a field for the display of large area design that, as an unwrapped cylindrical surface, could be compared with various body waist garments. In some the decoration is applied as a separate band stepped above the carination profile, as if it was indeed a waist-wrapped garment shown in the New Caledonian Site 13 collection (Sand 1999:40, 41). Sand notes that '[o]ne of the local characteristics of the carinated pots is the nearly systematic presence, over the main carination angle, of a parallel clay band, that forms a raised angle' (2001:67). This is illustrated in the profile of a pot from the New Caledonia Lapita Site 13 (Figure 12.3).

\section{Continuity from Lapita to later Oceanic fibre artefacts}

Comparisons of motifs from geographically separated collections have yielded data from the interaction phase of Lapita dispersal, with insights into questions of population dynamics, the chronology of design modification and debate about the range of communication between 'homeland' and founding settlements (Burley and Dickinson 2001; Cochrane et al. 2011:50; Dickinson 2006; Sand 2007; Summerhayes 2001; Summerhayes et al. 2010). The 'supplementary friezes' as defined by Siorat (1990:61) are important, and relatively neglected, features of Lapita design, first emphasised by Mead (1973:21) who regarded the design field as a space confined by multiple transverse decoration bands. With zone markers, they are a design convention that frames at least four common central motif themes (Chiu 2015:193). This effect can be regarded as comparable to plaited fabric designs where horizontal borders constrain the design field, often with decorative fringed edges seen in the repeating triangles marking the margin commonly seen in Lapita pots. Karen Coote's illustrations (Figure 12.3) from the New Caledonian Lapita Site WKO013A (Sand 2007:272) show complete designs capable of being rendered as textiles with curved tassel-edge friezes. Similar edge treatment is illustrated by Bedford et al. (2010:153). A feature of some Teouma pots seems intended to display the textile fringes more clearly by showing them curved and in relief (Figure 12.4). 

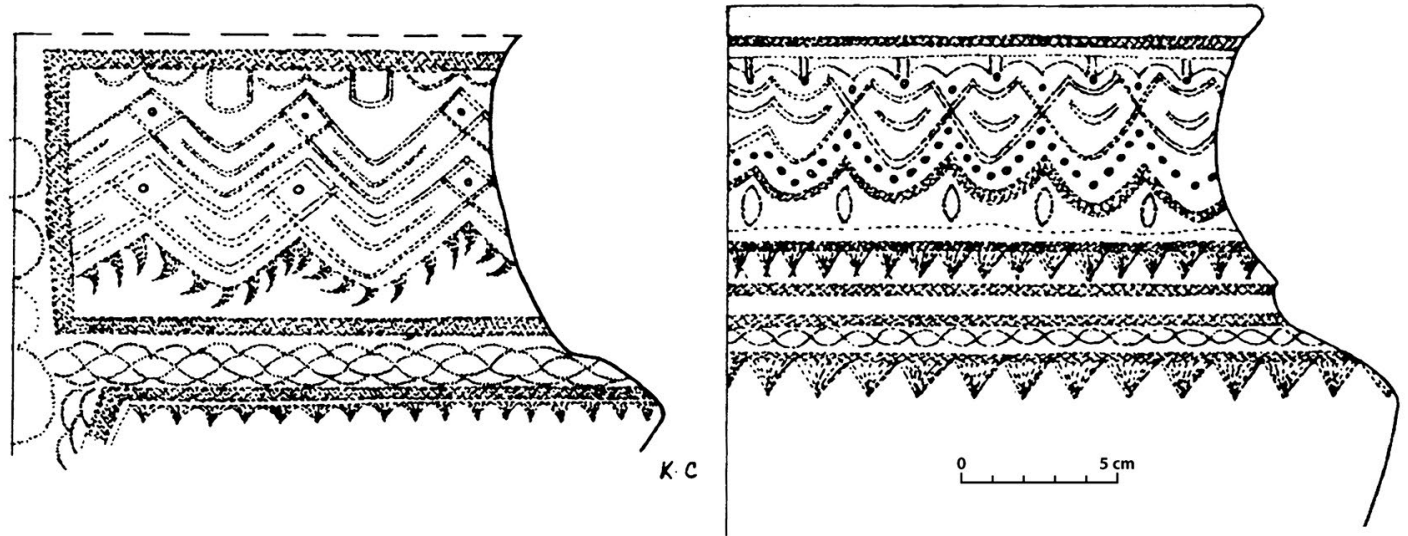

Figure 12.3. Drawings of two of the restored pots from the original New Caledonia Lapita site (WK0013A) by Karen Coote, in Sand (2007:272).

They show clear examples of the central patterns bounded by zone markers that appear to display pendant tassels or fringes. These are commonly seen in plaited textiles as ornamental edges. The profile of the pot on the right shows the raised carination edge that Sand notes (2001:67) is a characteristic feature of the New Caledonian Site 13 collection. This could be intended to display the ornamented carination as a 'wrapped' item, such as a waist garment.

Source: Reproduced courtesy of Christophe Sand.
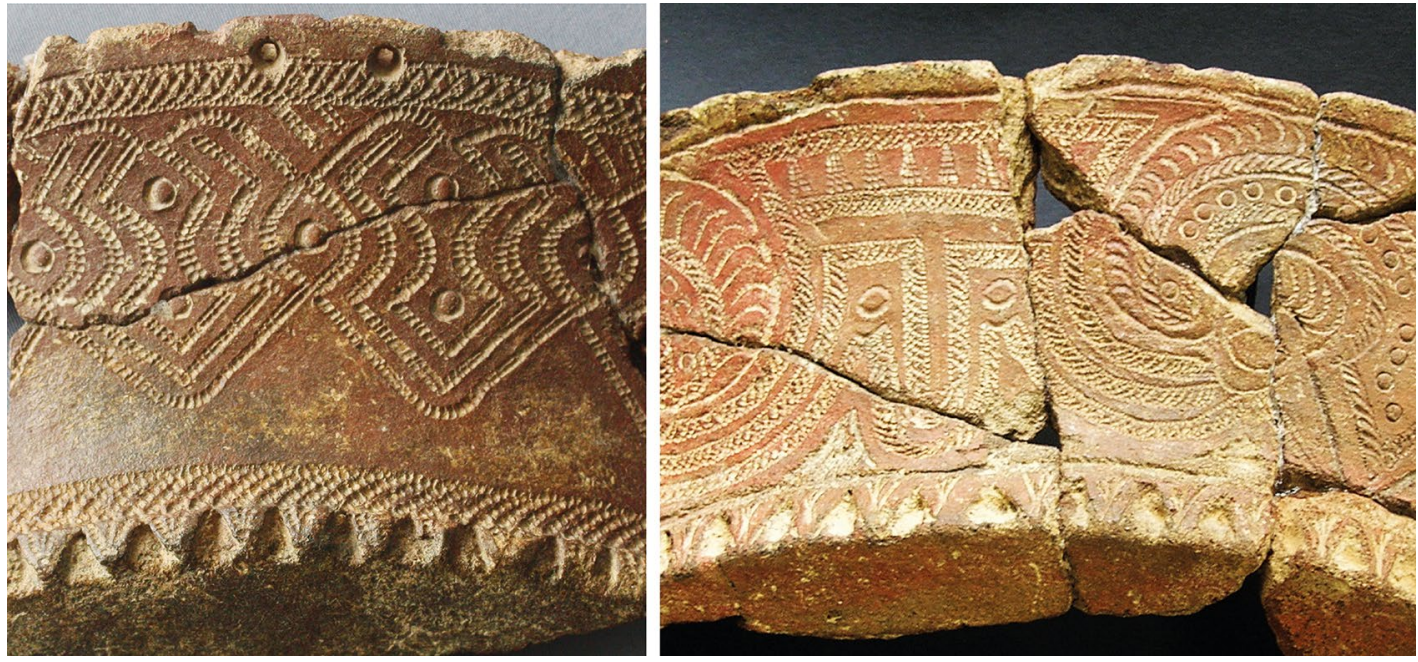

Figure 12.4. Two Lapita pots from Teouma showing the central decorated area bounded on the lower edge with striated triangular motifs that have been cut to emphasise their shapes in relief.

The effect is to present the entire design standing out above the vessel's form. This has the same effect as that described by Sand where the potter has decided to present the design on the surface rather than in the surface. This effect gives the impression again of a fabric skeuomorph.

Source: Stuart Bedford.

In this form, the ceremonial use of Lapita vessels can be seen as a display of the textile conveyed on its surface. Interestingly, the motifs most common in supplementary friezes from other Lapita sites are absent from the Samoan Lapita designs, according to Chiu's analysis (2015:190). However, Burley and LeBlanc (2015:177) describe a different outcome where less complex motifs/design elements taken from supplementary bands around these friezes were expanded, opened up, simplified and applied as principal decorative elements'. This outcome would indicate that the decorated vessels had reduced their motifs to an elemental resemblance to some simplified fabric connection, perhaps in the direction of 'fine mats'. This major change was given additional 
weight in the temporal and regional differentiation that led to the loss of Lapita design motifs and their accompanying pot forms in the formative Tonga-Samoa, and Eastern Fiji, Polynesian homeland (Clark and Murray 2006:108).

As Weiner (1989:34) noted in her definition of 'cloth', there are wealth items that play a central role in the evolution of political hierarchy in the Trobriand Islands and Samoa. She quotes a personal reference from Epeli Hau'ofa to the presence in the Tongan King's palace of stored fine mats over 300 years old (1989:67). Weiner (1989), Schoeffel (1999) and Herda (1999) underline the paramount ceremonial role of fine mats plaited from pandanus or hibiscus fibre in Samoa, a role elaborated in great detail for Tonga by Kaeppler (1999). Examples of prized garments made with banana leaf fibre on back-strap looms are illustrated by Hambruch and Eilers (1936:291-294) from Pohnpei. This technology has a limited distribution in Micronesia and is likely to be an introduction to Oceania later than the demise of Lapita. Nevertheless, these studies leave no doubt about the enduring importance of producing and displaying highly prized prestigious textiles embodying their own heirloom histories that re-enter into formative social events of birth, death, marriage, feasting and ascension to high status. If Lapita pottery was formerly integrated in these events, its role became redundant in west Polynesia. There is no doubt that continuing traditions of fibre work provided the two- and three-dimensional decorative arts with both mundane, prestige, power and ritual associations throughout Oceania.

The proposition here is that the separation of the ceramic from its important role in displaying the encircling fabric designs also separated its ceremonial potency in diminished form until its terminal separation around 2700 years ago in Tonga and Samoa, where the decorated clay pot became redundant. But the value of specially plaited products continued to be employed as significant markers of prestige and power in all Polynesian societies. The Lapita textile connection may have been stripped of its original smaller-scale ownership of uniquely designed pottery items over time, but eventually special plaited textiles became visually synonymous with hierarchies that signalled increased ritual power and leadership through their latent historical sacred pedigree, and that could extend over centuries as a trove of precious curated items. As 'symbols of sacred sovereignty' (Kaeppler 2008:87), valued fabrics persisted as far more durable signals of power than the diminished value of the pottery that originally bore the designs.

\section{References}

Ambrose, W.R. 1997. Contradictions in Lapita pottery, a composite clone. Antiquity 71:525-528. doi.org/10.1017/S0003598X00085306.

Ambrose, W.R. 2012. Oceanic tattooing and the implied Lapita ceramic connection. Journal of Pacific Archaeology 3(1):1-21.

Anson, D. 1986. Lapita pottery of the Bismarck Archipelago and its affinities. Archaeology in Oceania 21(3):157-165. doi.org/10.1002/j.1834-4453.1986.tb00144.x.

Anson, D. 1990. Aspiring to paradise. In M. Spriggs (ed.), Lapita design, form and composition: Proceedings of the Lapita Design Workshop, Canberra, December 1988, pp. 53-58. Occasional Papers in Prehistory 19. Department of Prehistory, RSPacS, The Australian National University, Canberra.

Bedford, S. 2006. The Pacific's earliest painted pottery: An added layer of intrigue to the Lapita debate and beyond. Antiquity 80:544-557. doi.org/10.1017/S0003598X00094023.

Bedford, S., M. Spriggs, R. Regenvanu, C. Macgregor, T. Kuautonga and M. Sietz 2007. The excavation, conservation and reconstruction of Lapita burial pots from the Teouma site, Efate, Central Vanuatu. In S. Bedford, C. Sand and S.P. Connaughton (eds), Oceanic explorations: Lapita and Western Pacific settlement, pp. 223-240. Terra Australis 26. ANU E Press, Canberra. doi.org/10.22459/TA26.2007. 
Bedford, S., C. Sand and R. Shing 2010. Lapita peoples/peoples/pipol: Oceanic ancestors/Ancêtres Océaniens/ Bubu blong ol man long Pasifik. Vanuatu Cultural Centre, Port Vila.

Bellwood, P. 1997. Prehistory of the Indo-Malaysian archipelago. Second edition. University of Hawai i Press, Honolulu.

Best, S. 2002. Lapita: A view from the east. New Zealand Archaeological Association Monograph 24. New Zealand Archaeological Association, Auckland.

Bolton, L. 1996. Tahigogana's sisters: Women, mats and landscape on Ambae. In J. Bonnemaison, K. Huffman, C. Kaufmann and D. Tryon (eds), Arts of Vanuatu, pp. 112-119. Crawford House, Bathurst.

Bolton, L. 2003. Unfolding the moon: Enacting women's Kastom in Vanuatu. University of Hawai'i Press, Honolulu.

Bolton, L. 2011. Baskets and belonging: Indigenous Australian histories. The British Museum Press, London.

Bonnemaison, J., K. Huffman, C. Kaufmann and D. Tryon (eds) 1996. Arts of Vanuatu. Crawford House, Bathurst.

Buck, P.H. (Te Rangi Hiroa) 1926. The evolution of Maori clothing. Journal of the Polynesian Society 138:111-149.

Buck, P.H. (Te Rangi Hiroa) 1930. Samoan material culture. Bernice P. Bishop Museum Bulletin 75. Bishop Museum Press, Honolulu.

Burley, D.V. and W.R. Dickinson 2001. Origin and significance of a founding settlement in Polynesia. Proceedings of the National Academy of Sciences 98(20):11829-11831. doi.org/10.1073/ pnas. 181335398.

Burley, D.V. and K. LeBlanc 2015. Obfuscating migration and exchange: The misconceptions of an Eastern Lapita Province. In C. Sand, S. Chiu and N. Hogg (eds), The Lapita Cultural Complex in time and space: Expansion routes, chronologies and typologies, pp. 173-184. Archeologia Pasifika 4. Institut d'archéologie de la Nouvelle-Calédonie et du Pacifique (IANCP), Nouméa.

Carson, M.T., H.-C. Hung, G.R. Summerhayes and P. Bellwood 2013. The pottery trail from Southeast Asia to Remote Oceania. The Journal of Island and Coastal Archaeology 8(1):17-36. doi.org/10.1080/ 15564894.2012.726941.

Casey, D.A. 1936. Pottery from Watom Island, Territory of New Guinea, ethnological notes. Memoirs of the National Museum of Victoria, Melbourne 9:90-97. doi.org/10.24199/j.mmv.1936.9.04.

Childe, V.G. 1956. Piecing together the past. Routledge and Kegan Paul, London.

Chiu, S. 2003. Social and economic meanings of Lapita pottery: A New Caledonian case. In C. Sand (ed.), Pacific archaeology: Assessments and prospects. Proceedings of the conference for the 50th anniversary of the first Lapita excavation, Kone-Nouméa, 2002, pp. 159-182. Les cahiers de l'archéologie en Nouvelle-Calédonie 15. Département Archéologie, Service des Musées et du Patrimoine de NouvelleCalédonie, Nouméa.

Chiu, S. 2005. Meanings of a Lapita face: Materialized social memory in ancient house societies. Taiwan Journal of Anthropology 3(1):1-47.

Chiu, S. 2007. Detailed analysis of Lapita face motifs: Case studies from Reef/Santa Cruz Lapita sites and New Caledonia Lapita site 13A. In S. Bedford, C. Sand and S.P. Connaughton (eds), Oceanic explorations: Lapita and Western Pacific settlement, pp. 241-264. Terra Australis 26. ANU E Press, Canberra. doi.org/10.22459/TA26.2007. 
Chiu, S. 2015. Where do we go from here? Social relatedness reflected by motif analysis. In C. Sand, S. Chiu and N. Hogg (eds), The Lapita Cultural Complex in time and space: Expansion routes, chronologies and typologies, pp. 185-206. Archeologia Pasifika 4. IANCP, Nouméa.

Clark, G. 2007. Specialisation, standardisation and Lapita ceramics. In S. Bedford, C. Sand and S.P. Connaughton (eds), Oceanic explorations: Lapita and Western Pacific settlement, pp. 289-299. Terra Australis 26. ANU E Press, Canberra. doi.org/10.22459/TA26.2007.

Clark, G. and T. Murray 2006. Decay characteristics of the Eastern Lapita design system. Archaeology in Oceania 41(3):107-117. doi.org/10.1002/j.1834-4453.2006.tb00619.x.

Cochrane, E.E., I.C. Rivera-Collazo and E. Walsh 2011. New evidence for variation in colonisation, cultural transmission, and subsistence from Lapita (2900 BP) to the Historic Period in southwestern Fiji. Journal of Pacific Archaeology 2(1):40-55.

D’Alleva, A. 1998. Arts of the Pacific Islands. Harry N. Abrams, New York.

David, B., I.J. McNiven, T. Richards, S.P. Connaughton, M. Leavesley, B. Barker and C. Rowe 2011. Lapita sites in the Central Province of mainland Papua New Guinea. World Archaeology 43(4):576-593. doi.org/10.1080/00438243.2011.624720.

Davidson, J.M. 2012. Intrusion, integration and innovation on small and not-so-small islands with particular reference to Samoa. Archaeology in Oceania 47:1-13. doi.org/10.1002/j.1834-4453.2012. tb00110.x.

Dickinson, W.R. 2006. Temper sands in prehistoric Oceanian pottery: Geotectonics, sedimentology, petrography, provenance. Geological Society of America, Special Paper 406. Geological Society of America, Boulder, Colorado. doi.org/10.1130/2006.2406.

Dickinson, W.R. and R. Shutler Jr 2000. Implications of petrographic temper analysis for Oceanian Prehistory. Journal of World Prehistory 14(3):203-266. doi.org/10.1023/A:1026557609805.

Ellen, R. 2009. A modular approach to understanding the transmission of technical knowledge. Journal of Material Culture 14(2):243-277. doi.org/10.1177/1359183509103065.

Emery, I. 1966. The primary structure of fabrics. The Textile Museum, Washington DC.

Emory, K.P. 1975. Material culture of the Tuamotu Archipelago. Pacific Anthropological Records 22. Bishop Museum Press, Honolulu.

Evans, M. and R. Ngarimu 2005. The art of Mãori weaving, the eternal thread: Te Aho Mutunga Kore. Huia Publishers, Wellington.

Gill, W.W. 1885. Jottings from the Pacific. The Religious Tract Society, London.

Gorecki, P. 1996. The initial colonisation of Vanuatu. In J. Bonnemaison, K. Huffman, C. Kaufmann and D. Tryon (eds), Arts of Vanuatu, pp. 62-65. Crawford House, Bathurst.

Green, R.C. 1979a. Lapita. In J.D. Jennings (ed.), The prehistory of Polynesia, pp. 27-60. Harvard University Press, Cambridge, Mass. doi.org/10.4159/harvard.9780674181267.c3.

Green, R.C. 1979b. Early Lapita art from Polynesia and Island Melanesia: Continuities in ceramic, barkcloth, and tattoo decorations. In S.M. Mead (ed.), Exploring the visual art of Oceania, pp. 13-31. University of Hawai'i Press, Honolulu.

Green, R.C. 1985. Comment: Spriggs' 'The Lapita Cultural Complex'. Journal of Pacific History 20(4):220-224. doi.org/10.1080/00223348508572523. 
Green, R.C. 1990. Lapita design analysis: The Mead system and its use, a potted history. In M. Spriggs (ed.), Lapita design, form and composition. Proceedings of the Lapita Design Workshop, Canberra, December 1988, pp. 33-52. Occasional Papers in Prehistory 19. Department of Prehistory, RSPacS, The Australian National University, Canberra.

Green, R.C. 1991. The Lapita Cultural Complex: Current evidence and proposed models. Bulletin of the Indo-Pacific Prehistory Association 11:295-305. doi.org/10.7152/bippa.v11i0.11393.

Green, R.C. 2002. Rediscovering the social aspects of Ancestral Oceanic Societies through archaeology, linguistics and ethnology. In S. Bedford, C. Sand and D. Burley (eds), Fifty years in the field. Essays in honour and celebration of Richard Shutler Jr's archaeological career, pp. 21-35. New Zealand Archaeological Association Monograph 25. New Zealand Archaeological Association, Auckland.

Groves, M. 1960. Motu pottery. Journal of the Polynesian Society 69(1):3-22.

Haddon, A.C. 1895. Evolution in art: As illustrated by the life-histories of designs. The Contemporary Science Series, Ed. Havelock Ellis. Walter Scott, London. doi.org/10.5479/sil.120683.39088002 611119.

Hambruch, P. and A. Eilers, 1936. Ponape, Volume 2. G. Thilenius (ed.), Ergebnisse der Südsee-Expedition 1908-1910, II Ethnographie: B. Micronesien, Band 7. Friedrichsen-De Gruyter, Hamburg.

Herda, P. 1999. The changing texture of textiles in Tonga. Journal of the Polynesian Society 108(2):149-167.

Huffman, K.W. 1996. Woven female waistbands of northern Vanuatu. In J. Bonnemaison, K. Huffman, C. Kaufmann and D. Tryon (eds), Arts of Vanuatu, pp. 120-122. Crawford House, Bathurst.

Hung, H.-C., M.T. Carson, P. Bellwood, F.Z. Campos, P.J. Piper, E. Dizon, M.J.L.A. Bolunia, M. Oxenham and Z. Chi 2011. The first settlement of Remote Oceania: The Philippines to the Marianas. Antiquity 85:909-926. doi.org/10.1017/S0003598X00068393.

Intoh, M. 1999. Cultural contacts between Micronesia and Melanesia. In J.-C. Galipaud and I. Lilley (eds), The Pacific from 5000-2000 BP: Colonisation and transformations, pp. 407-422. IRD Éditions, Paris.

Kaeppler, A.L. 1999. Kie Hingoa: Mats of power, rank, prestige and history. Journal of the Polynesian Society 108(2):168-232.

Kaeppler, A.L. 2008. The Pacific arts of Polynesia and Melanesia. Oxford University Press, New York.

Kirch, P.V. 1997. The Lapita peoples: Ancestors of the Oceanic World. Blackwell, Oxford.

Kirch, P.V. 2000. On the road of the winds: An archaeological history of the Pacific Islands before European contact. University of California Press, Berkeley.

Kooijman, S. 1988. Polynesian barkcloth. Shire Publications, Aylesbury.

Krämer, A. 1926. Palau, Volume 3. G. Thilenius (ed.), Ergebnisse der Südsee-Expedition 1908-1910, II. Ethnographie: B. Micronesien, Band 3. Friedrichsen-De Gruyter, Hamburg.

Kubary, J.S. 1895. Ethnographische Beiträge zur Kenntnis des Karolinen Archipels. P.W.M. Trap, Leipzig.

Lewis, A.B. 1973. Decorative art of New Guinea. Reprint of Field Museum, Chicago, publications'Decorative Art of New Guinea: Incised Designs' (1925) and 'Carved and Painted Designs from New Guinea' (1931). Dover Publications, New York.

Marshall, Y. 1985. Who made the Lapita pots? A case study in gender archaeology. Journal of the Polynesian Society 94(3):205-233.

Marshall, Y. 2008. The social lives of lived and inscribed objects: a Lapita perspective. Journal of the Polynesian Society 117(1):59-101. 
Maude, H.C. and H.E. Maude 1958. String figures from the Gilbert Islands. Memoirs of the Polynesian Society 13. Polynesian Society, Wellington.

Mead, S.M. 1971. An analysis of form and decoration in Polynesian adze hafts. Journal of the Polynesian Society 80(4):485-496.

Mead, S.M. 1973. The decorative system of the Lapita potters of Sigatoka, Fiji. Memoirs the Polynesian Society 38, Part 2. Polynesian Society, Wellington (supplement to the Journal of the Polynesian Society).

Mead, S.M. 1974. Formal and iconic analysis of Polynesian hafted adzes: A preliminary statement of interrelationships within Oceania. In N. Barnard (ed.), Early Chinese art and its possible influence on the Pacific Basin, pp. 723-741. Authorised Taiwan Edition, Taipei.

Mead, S.M., L. Birks, H. Birks and E. Shaw 1973. The Lapita pottery style of Fiji and its associations. Memoirs of the Polynesian Society 38, Part 1. Polynesian Society, Wellington (supplement to the Journal of the Polynesian Society).

Ohnemus, S. 2002. The rich variety of textile art. In C. Kaufmann, C. Kocher Schmid and S. Ohnemus (eds), Admiralty Islands art from the south seas, pp. 53-61. Museum Rietburg, Zurich.

Pendergrast, M. 1987. Te Aho Tapu: The sacred thread. University of Hawai'i Press, Honolulu.

Pendergrast, M. 2000. Tikopian tattoo. Bulletin of the Auckland Museum 18. Auckland Museum, Auckland.

Pendergrast, M. 2005. Ka Tahi, hei Tama tū Tama: Mãori fibre techniques. Reed Books, Auckland.

Sand, C. 1999. Archéologie des origines: Le Lapita Calédonien/Archaeology of the origins: New Caledonia's Lapita. Les cahiers de l'archéologie en Nouvelle-Calédonie 10. Département Archéologie, Service des Musées et du Patrimoine de Nouvelle-Calédonie, Nouméa.

Sand, C. 2001. Evolutions in the Lapita Cultural Complex: A view from the Southern Lapita Province. Archaeology in Oceania 36(2):65-76. doi.org/10.1002/j.1834-4453.2001.tb00479.x.

Sand, C. 2007. Looking at the big motifs: A typology of the central band decorations of the Lapita ceramic tradition of New Caledonia (southern Melanesia) and preliminary regional comparisons. In S. Bedford, C. Sand and S.P. Connaughton (eds), Oceanic explorations: Lapita and Western Pacific settlement, pp. 265-285. Terra Australis 26. ANU E Press, Canberra. doi.org/10.22459/ta26.2007.16.

Sand, C. 2010. Southern Lapita: The case of New Caledonia. In C. Sand and S. Bedford (eds), Lapita: Ancêtres Océaniens/Oceanic ancestors, pp. 190-207. Musée du quai Branly and Somogy, Paris.

Sand, C. 2015. Comparing Lapita pottery forms in the Southwestern Pacific: A case study. In C. Sand, S. Chiu and N. Hogg (eds), The Lapita Cultural Complex in time and space: Expansion routes, chronologies and typologies, pp. 125-171. Archeologia Pasifika 4. IANCP, Nouméa.

Schoeffel, P. 1999. Samoan exchange and 'fine mats': An historical reconsideration. Journal of the Polynesian Society 108(2):117-148.

Sharp, N.D. 1988. Style and substance: A reconsideration of the Lapita decorative system. In P.V. Kirch and T.L. Hunt (eds), Archaeology of the Lapita Cultural Complex: A critical review, pp. 61-81. Thomas Burke Memorial Washington State Museum Research Report No 5. Burke Museum, Seattle.

Siorat, J.-P. 1990. A technological analysis of Lapita pottery decoration. In M. Spriggs (ed.), Lapita design, form and composition. Proceedings of the Lapita Design Workshop, Canberra, December 1988, pp. 59-82. Occasional Papers in Prehistory 19. Department of Prehistory, RSPacS, The Australian National University, Canberra. 
Specht, J., T. Denham, J. Goff and J.E. Terrell 2014. Deconstructing the Lapita Cultural Complex in the Bismarck Archipelago. Journal of Archaeological Research 22(2):89-140. doi.org/10.1007/s10814013-9070-4.

Speiser, F. 1996 [orig. 1923]. Ethnology of Vanuatu. Translated by D.Q. Stephenson. Crawford House, Bathurst.

Spriggs, M. (ed.) 1990. Lapita design, form and composition. Proceedings of the Lapita Design Workshop, Canberra, December 1988. Occasional Papers in Prehistory 19. Department of Prehistory, RSPacS, The Australian National University, Canberra.

Spriggs, M. 1993. How much of the Lapita design system represents the human face? In P.J.C. Dark and R.G. Rose (eds), Artistic heritage in a changing Pacific, pp. 7-14. University of Hawai'i Press, Honolulu.

Spriggs, M. 2002. They've grown accustomed to your face. In S. Bedford, C. Sand and D. Burley (eds), Fifty years in the field. Essays in honour and celebration of Richard Shutler Jr's archaeological career, pp. 51-57. New Zealand Archaeological Association Monograph 25. New Zealand Archaeological Association, Auckland.

Summerhayes, G.R. 2001. Lapita in the far west: Recent developments. Archaeology in Oceania 36(2):5363. doi.org/10.1002/j.1834-4453.2001.tb00478.x.

Summerhayes, G.R. and J. Allen 2007. Lapita writ small? Revisiting the Austronesian colonisation of the Papuan south coast. In S. Bedford, C. Sand and S.P. Connaughton (eds), Oceanic explorations: Lapita and Western Pacific settlement, pp. 97-122. Terra Australis 26. ANU E Press, Canberra. doi.org/ 10.22459/TA26.2007.

Summerhayes, G.R., E. Matisoo-Smith, H. Mandui, J. Allen, J. Specht, N. Hogg and S. McPherson 2010. Tamuarawai (EQS): An Early Lapita site on Emirau, New Ireland, PNG. Journal of Pacific Archaeology 1(1):62-75.

Taylor, D. 1960. The relation of matplaiting to barkcloth decoration in Polynesia. Journal of the Polynesian Society 69(1):43-53.

Terrell, J.E. and E.M. Schechter 2009. The meaning and importance of the Lapita face motif. Archaeology in Oceania 44:45-55. doi.org/10.1002/j.1834-4453.2009.tb00046.x.

Thomas, N. 1999. The case of the misplaced ponchos: Speculations concerning the history of cloth in Polynesia. Journal of Material Culture 4(1):5-20. doi.org/10.1177/135918359900400101.

Thomas, N. 2012. European incursions 1765-1880. In P. Brunt, N. Thomas and S. Ramage (eds), Art in Oceania: A new history, pp. 271-297. Yale University Press, New Haven and London.

Torrence, R. and P. Swadling 2008. Social networks and the spread of Lapita. Antiquity 82: 600-616. doi.org/10.1017/S0003598X00097258.

Tsang, C.-H. 2007. Recent archaeological discoveries in Taiwan and northern Luzon, Implications for Austronesian expansion. In S. Chiu and C. Sand (eds), From Southeast Asia to the Pacific: Archaeological perspectives on the Austronesian expansion and the Lapita Cultural Complex, pp. 75-103. Centre for Archaeological Studies, Research Centre of Humanities and Social Sciences. Academia Sinica, Taipei.

Walter, A. 1996. The feminine art of mat-weaving on Pentecost. In J. Bonnemaison, K. Huffman, C. Kaufmann and D. Tryon (eds), Arts of Vanuatu, pp. 100-109. Crawford House, Bathurst.

Weiner, A.B. 1989. Why cloth? Wealth, gender and power in Oceania. In A.B. Weiner and J. Schneider (eds), Cloth and human experience, pp. 33-72. Smithsonian Institution Press, Washington DC. 
This text is taken from Debating Lapita: Distribution, Chronology, Society and Subsistence, edited by Stuart Bedford and Matthew Spriggs, published 2019 by ANU Press,

The Australian National University, Canberra, Australia.

doi.org/10.22459/TA52.2019.12 